\title{
PERAN KONTRAK PSIKOLOGIS RELASIONAL DAN TRANSAKSIONAL SEBAGAI PREDIKTOR PERILAKU KERJA KONTRAPRODUKTIF ORGANISASI DAN INTERPERSONAL
}

\author{
Ismoro Reza Prima Putra1, P. Tommy Y.S. Suyasa ${ }^{2}$, \& Raja Oloan Tumanggor ${ }^{3}$ \\ ${ }^{1}$ Prodi Magister Psikologi Profesi, Fakultas Psikologi, Universitas Tarumanagara, Jakarta \\ Email: ismoro.717171021@stu.untar.ac.id \\ ${ }^{2}$ Fakultas Psikologi, Universitas Tarumanagara, Jakarta \\ Email: tommys@fpsi.untar.ac.id \\ ${ }^{3}$ Fakultas Psikologi, Universitas Tarumanagara, Jakarta \\ Email:rajat@fpsi.untar.ac.id
}

Masuk : 25-03-2020, revisi: 28-04-2020, diterima untuk diterbitkan : 30-04-2020

\begin{abstract}
Counterproductive work behavior occured in Indonesia, especially in companies. Companies that have many employees with counterproductive work behavior will have a negative impact on the productivity and business of the company. Counterproductive work behavior can be explained by psychological contracts held by each employee. Therefore, this study has examined the role of relational and transactional psychological contracts as predictors of organizational and interpersonal counterproductive work behavior. Counterproductive work behavior was defined as behavior that violates organizational norms and is detrimental to the organization and the individuals within it. Meanwhile, employee psychological contracts were defined as employee perceptions of behavioral obligations that must be given to the organization. Participants in this study were 378 employees in one company in Jakarta. Counterproductive work behavior measurement tool used a workplace deviance scale with a total of 48 items. Meanwhile, psychological contract measurement tools consist of 33 items. The analytical method that has been used is regression and bootstrapping. The results showed that relational psychological contracts play a negative role in predicting organizational counterproductive work behavior $(\beta=-0.308, p<0.01)$ and interpersonal $(\beta=-0.307, p$ $<0.01$ ). Meanwhile, transactional psychological contracts play a positive role in predicting counterproductive organizational work behavior $(\beta=0.199, p<0.01)$ and interpersonal $(\beta=0.221, p<0.01)$. Through the MannWhitney $U$ test there were differences in relational psychological contracts $(U=6179.00, p<0.05)$, organizational counterproductive work behavior $(U=3332.50, p<0.05)$, and interpersonal counterproductive work behavior $(U=$ 4491.00, $p<0.05)$ between male employees and female employees. Meanwhile, there was no difference in the transactional psychological contract between male and female employees $(U=8321.00, p>0.05)$. Implications for theory and practice are discussed.
\end{abstract}

Keywords: relational psychological contracts, transactional psychological contracts, organizational counterproductive work behavior $(C W B-O)$, counterproductive interpersonal work behavior $(C W B-I)$

\footnotetext{
ABSTRAK

Perilaku kerja kontraproduktif banyak terjadi di Indonesia khususnya di perusahaan. Perusahaan yang banyak memiliki karyawan dengan perilaku kerja kontraproduktif akan memiliki dampak negatif terhadap produktivitas dan bisnis perusahaan. Perilaku kerja kontraproduktif dapat dijelaskan oleh kontrak psikologis yang dimiliki oleh setiap karyawan. Oleh karena itu, penelitian ini menguji peran kontrak psikologis relasional dan transaksional sebagai prediktor terjadinya perilaku kerja kontraproduktif organisasi dan interpersonal. Perilaku kerja kontraproduktif didefinisikan sebagai perilaku yang melanggar norma-norma organisasi dan merugikan organisasi maupun individu di dalamnya. Sementara itu, kontrak psikologis karyawan didefinisikan sebagai persepsi karyawan terhadap kewajiban perilaku yang harus diberikan kepada organisasinya. Partisipan dalam penelitian ini adalah 378 karyawan di salah satu perusahaan di Jakarta. Alat ukur perilaku kerja kontraproduktif menggunakan workplace deviance scale dengan total 48 item. Sementara itu, alat ukur kontrak psikologis terdiri dari 33 item. Metode analisis yang digunakan adalah regresi dan bootstrapping. Hasil penelitian menunjukkan bahwa kontrak psikologis relasional berperan negatif dalam memprediksi perilaku kerja kontraproduktif organisasi $(\beta=-0.308, \mathrm{p}<0.01)$ dan interpersonal $(\beta=-0.307, \mathrm{p}<0.01)$. Sementara itu, kontrak psikologis transaksional berperan positif dalam memprediksi perilaku kerja kontraproduktif organisasi $(\beta=0.199, \mathrm{p}<0.01)$ dan interpersonal $(\beta=0.221, \mathrm{p}<0.01)$. Melalui uji Mann-Whitney $U$ terdapat perbedaan kontrak psikologis relasional $(U=6179.00, \mathrm{p}<0.05)$, perilaku kerja kontraproduktif organisasi $(U=3332.50, \mathrm{p}<0.05)$, dan perilaku kerja kontraproduktif interpersonal $(U=4491.00, \mathrm{p}<0.05)$ antara karyawan laki-laki dan karyawan
} 
perempuan. Sementara itu, kontrak psikologis transaksional antara karyawan laki-laki dan karyawan perempuan tidak terdapat perbedaan $(U=8321.00, \mathrm{p}>0.05)$. Hasil dari penelitian ini, baik secara teori maupun praktik, akan didiskusikan lebih lanjut.

Kata Kunci: kontrak psikologis relasional, kontrak psikologis transaksional, perilaku kerja kontraproduktif organisasi (CWB-O), perilaku kerja kontraproduktif interpersonal (CWB-I)

\section{PENDAHULUAN}

\section{Latar Belakang}

Perilaku kerja kontraproduktif atau counterproductive work behaviour (CWB) didefinisikan sebagai perilaku sukarela yang melanggar norma-norma organisasi dan mengancam kesejahteraan organisasi ataupun anggotanya (Bennett \& Robinson, 1995). Penney dan Spector (2005) mengemukakan bahwa penelitian mengenai perilaku kerja kontraproduktif akan menjadi topik yang sangat menarik bagi organisasi dan para peneliti karena hubungannya terkait dengan biaya besar yang disebabkan oleh perilaku ini. Perilaku kerja kontraproduktif dapat menyebabkan karyawan mengalami stres dan penurunan kepuasan kerja serta menyebabkan organisasi mengalami penurunan produktivitas (Penney \& Spector, 2005). Coffin (2003, dalam Yang, Johnson, Zhang, Spector, \& Xu, 2012) menunjukkan bahwa perilaku kerja kontraproduktif telah merugikan organisasi di USA sekitar $\$ 50$ miliar per tahun dan menyebabkan $20 \%$ gagalnya bisnis suatu perusahaan. Sementara itu, perilaku kerja kontraproduktif interpersonal akan menurunkan kualitas kehidupan kerja diantara anggota kelompok (Aubé, Rousseau, \& Tremblay, 2011). Banyaknya dampak kerugian yang ditimbulkan akibat perilaku kerja kontraproduktif ini perlu menjadi perhatian lebih lanjut oleh peneliti.

Dalam beberapa tahun terakhir, CWB dapat dijelaskan oleh kontrak psikologis (Bordia, Restubog, \& Tang, 2008; Erkutlu \& Chafra, 2013; Griep, Vantilborgh, \& Jones, 2018; Mai, Christian, Ellis, \& Porter, 2016). Sehingga, berdasarkan hasil penelitian beberapa tahun terakhir tersebut peneliti memilih kontrak psikologis sebagai variabel bebas. Rousseau (1995) mengatakan bahwa kontrak psikologis didefinisikan sebagai persepsi karyawan tentang kewajiban timbal balik antara mereka dan organisasinya. Kontrak psikologis terdiri dari dua jenis yaitu transaksional kontrak dan relasional kontrak, setiap individu dapat memiliki salah satu dari jenis kontrak tersebut ataupun dua-duanya. Individu yang memiliki jenis kontrak transaksional ketika bekerja hanya berfokus pada "tugas-tugas yang hanya tertuang di dalam kontrak kerjanya, hasil kerja yang jangka pendek, serta orientasi pada imbalan atas apa yang telah dikerjakannya" (Robinson \& Morrison, 1997).

Mai et al. (2016) melalui hasil penelitiannya, mengatakan bahwa dua jenis kontrak psikologis yang dimiliki oleh karyawan dapat mempengaruhi perilaku kerja kontraproduktif maupun perilaku kewargaan organisasi. Bordia et al. (2008) dan Griep et al. (2018) juga menjelaskan bahwa pelanggaran kontrak psikologis karyawan dapat memprediksi terjadinya perilaku kerja kontraproduktif organisasi dan interpersonal. Erkutlu et al. (2013) melalui hasil penelitiannya juga mengatakan bahwa pelanggaran terhadap kontrak psikologis dapat menyebabkan terjadinya perilaku kerja kontraproduktif organisasi.

Berdasarkan penelitian yang sudah ada (Bordia, Restubog, \& Tang, 2008; Erkutlu \& Chafra, 2013; Griep, Vantilborgh, \& Jones, 2018; Mai, Christian, Ellis, \& Porter, 2016), belum ada peneliti yang lebih detail menjelaskan hubungan antar kedua dimensi dari variabel tersebut. Sehingga, terkait dua jenis kontrak psikologis yang ada, belum ada penelitian yang menjelaskan hubungannya dengan perilaku kerja kontraproduktif organisasi (CWB-O) dan perilaku kerja kontraproduktif interpersonal (CWB-I) yang memiliki tingkat koefisien korelasi yang berbeda-beda. Hal ini dirasa oleh peneliti menjadi penting karena hasil koefisien korelasi yang berbeda dari CWB-O \& CWB-I 
dapat digunakan oleh perusahaan atau organisasi ketika memberikan treatment kepada karyawan untuk mengurangi perilaku tersebut dan dapat melengkapi hasil penelitian sebelumnya. Selain itu, CWB yang tinggi dalam suatu organisasi dapat mengakibatkan rendahnya job satisfaction (Organ, 1977); dan organizational justice (Fox, Spector, \& Miles, 2001).

Sementara itu, dengan mengetahui jenis kontrak psikologis yang dimiliki oleh karyawan akan berguna bagi organisasi dalam memberikan intervensi yang tepat untuk membuat semua karyawannya memiliki kontrak psikologis yang bersifat relasional. Rousseau (1995) mengatakan bahwa karyawan yang memiliki kontrak psikologis relasional berkontribusi untuk mewujudkan organisasi yang efektif melalui perilaku kewargaan organisasi (OCB), sementara karyawan yang memiliki kontrak psikologis transaksional dapat mengakibatkan perilaku kerja kontraproduktif dalam organisasi. Oleh karena itu, sesuai dengan fenomena perilaku kerja kontraproduktif yang terjadi di PT.X yaitu seperti angka absenteesim yang tinggi dan banyaknya karyawan yang melakukan penggelapan dana milik perusahaan. Peneliti ingin melihat peran kontrak psikologis relasional dan transaksional sebagai prediktor perilaku kerja kontraproduktif organisasi dan interpersonal.

Berdasarkan latar belakang yang telah dijelaskan sebelumnya, peneliti ingin melihat peran kontrak psikologis relasional dan transaksional sebagai prediktor perilaku kerja kontraproduktif organisasi dan interpersonal. Hipotesis yang diajukan dalam penelitian ini terbagi menjadi 2 dimana setiap hipotesis memiliki sub-hipotesis masing-masing. Hipotesis $1_{\mathrm{a}}$ adalah kontrak psikologis relasional berperan negatif sebagai prediktor perilaku kerja kontraproduktif yang ditujukan pada organisasi (CWB-O). Hipotesis $1_{\mathrm{b}}$ adalah kontrak psikologis relasional berperan negatif sebagai prediktor perilaku kerja kontraproduktif yang ditujukan pada interpersonal (CWB-I). Hipotesis 2 adalah kontrak psikologis transaksional berperan positif sebagai prediktor perilaku kerja kontraproduktif yang ditujukan pada organisasi (CWB-O). Hipotesis 2 b adalah kontrak psikologis transaksional berperan positif sebagai prediktor perilaku kerja kontraproduktif yang ditujukan pada interpersonal (CWB-I).

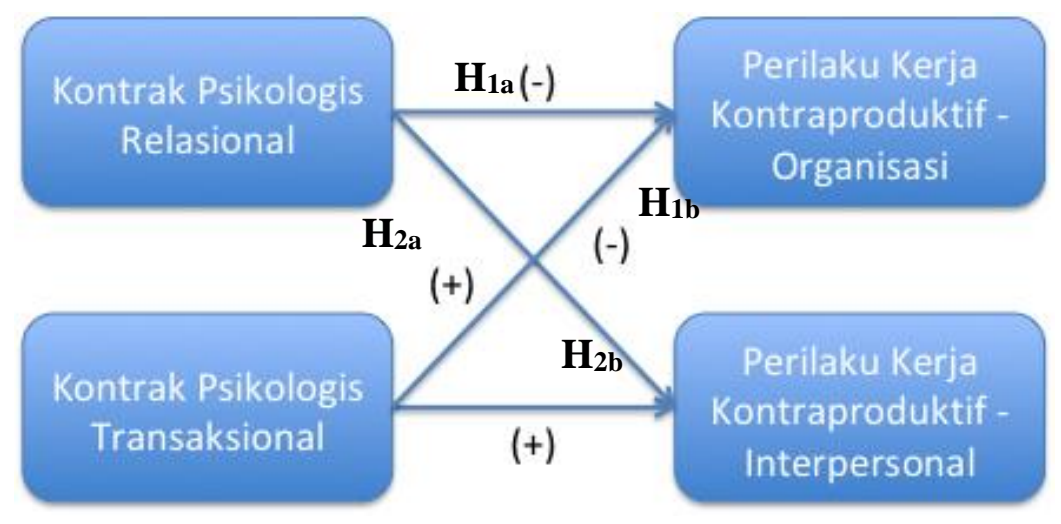

Gambar 1. Kerangka Berpikir

\section{METODE PENELITIAN}

\section{Partisipan dan Prosedur Penelitian}

Partisipan dalam penelitian ini berjumlah 378 orang karyawan dari berbagai departemen baik karyawan tetap maupun karyawan kontrak di perusahaan. Partisipan tidak dibatasi pada jenis kelamin tertentu dan memiliki rentang usia dari 18 tahun hingga 53 tahun. Partisipan rata-rata telah bekerja di perusahaan selama 6 tahun. Berdasarkan 378 data yang diperoleh, sebanyak 327 orang $(86,51 \%)$ berjenis kelamin laki-laki dan 51 orang $(13,49 \%)$ berjenis kelamin perempuan. 
Berdasarkan tingkat pendidikan partisipan, sebanyak 3 orang $(0,9 \%)$ adalah lulusan SMP, 305 orang $(80,5 \%)$ lulusan SMA/SMK, 11 orang $(2,9 \%)$ lulusan Diploma, 52 orang $(13,7 \%)$ lulusan S1, dan 7 orang (2\%) lulusan S2. Berdasarkan tingkat jabatan partisipan, sebanyak 287 orang $(76 \%)$ memiliki jabatan sebagai operator, 45 orang (12\%) memiliki jabatan sebagai staff, 36 orang $(9,5 \%)$ memiliki jabatan sebagai section head, 8 orang (2\%) sebagai department head, dan 2 orang $(0,5 \%)$ sebagai division head. Berdasarkan departemen partisipan dalam bekerja, sebanyak 295 orang $(78 \%)$ bekerja pada departemen operasional, 42 orang $(11 \%)$ bekerja pada departemen marketing, 9 orang $(2,5 \%)$ bekerja pada departemen human resources, 15 orang (4\%) bekerja pada departemen finance \& accounting, 13 orang (3,5\%) bekerja pada departemen general affair, dan 4 orang $(1 \%)$ bekerja pada departemen IT. Pendekatan melalui tatap muka langsung dilakukan kepada 157 karyawan dengan memberikan link penelitian dan pendekatan melalui whatsapp dilakukan pada 181 karyawan dengan cara memberikan link kuesioner penelitian dan meminta kesediaan partisipan untuk membantu mengisi kuesioner tersebut.

\section{Instrumen Penelitian}

Peneliti menggunakan workplace deviance scale untuk mengukur perilaku kerja kontraproduktif yang terdiri dari 28 butir milik Bennett dan Robinson (2000) dan telah diadaptasi ke dalam bahasa Indonesia menjadi 48 butir oleh Suyasa (2018), alat ukur yang telah diadaptasi ini memiliki koefisien alpha cronbach 0.915 - 0.939. Skala yang digunakan adalah skala rating scale dengan rentang 0-5 yang menunjukkan jumlah dilakukannya perilaku sesuai dengan yang tertera pada butir alat ukur ( 0 kali dalam sebulan/tidak pernah -5 kali atau lebih dalam sebulan). Untuk mengukur kontrak psikologis, penulis menggunakan alat ukur yang dikembangkan oleh Millward dan Hopkins (1998) dengan total 33 item dan telah diadaptasi ke dalam bahasa Indonesia oleh penulis. Alat ukur ini terdiri dari 22 item positif dan 11 item negatif dan diukur menggunakan skala likert 1-5 dari respon sangat tidak setuju sampai sangat setuju.

CWBO. Dimensi organizational deviance diukur dengan menggunakan 28 butir. Contoh butir pada dimensi organizational deviance adalah "membiarkan tugas yang belum selesai untuk dikerjakan keesokan harinya" dan "berusaha menambah/memperpanjang waktu istirahat yang telah ditentukan". Definsi operasional dari dimensi ini adalah semakin tinggi skor pada dimensi organizational deviance, maka semakin tinggi karyawan melakukan aktivitas penyimpangan terhadap perusahaan. Nilai Cronbach's Alpha pada dimensi organizational deviance tergolong reliabel (0.939).

CWBI. Dimensi interpersonal deviance diukur dengan menggunakan 20 butir. Contoh butir pada dimensi interpersonal deviance adalah "membicarakan atasan/rekan kerja sebagai bahan guyon/bercanda" dan "di lingkungan tempat kerja, mengekspresikan perasaan kesal/marah terhadap orang lain". Definisi operasional dari dimensi ini adalah semakin tinggi skor pada dimensi interpersonal deviance, maka semakin tinggi karyawan melakukan aktivitas penyimpangan terhadap individu. Nilai Cronbach's Alpha pada dimensi interpersonal deviance tergolong reliabel $(0.915)$.

Kontrak Psikologis Relasional. Dimensi kontrak psikologis relasional terdiri dari 13 butir. Contoh butir pada dimensi kontrak psikologis relasional adalah "saya merasa perusahaan memberikan timbal balik yang sesuai kepada karyawannya sesuai dengan hasil kerja yang telah mereka lakukan untuk perusahaan" dan "dengan masa kerja dan kerja keras yang telah saya lakukan, saya yakin perusahaan akan memberikan promosi karir bagi saya". Nilai Cronbach's Alpha pada dimensi kontrak psikologis relasional tergolong reliabel (0.756). 
Kontrak Psikologis Transaksional. Dimensi kontrak psikologis transaksional terdiri dari 20 butir. Contoh butir pada dimensi kontrak psikologis transaksional adalah "saya tidak terlalu peduli dengan apa yang terjadi di tempat kerja saya" dan "saya memilih untuk pulang pada saat jam pulang kerja padahal pekerjaan sedikit lagi sudah selesai". Nilai Cronbach's Alpha pada dimensi kontrak psikologis transaksional tergolong cukup reliabel (0.589).

\section{HASIL DAN PEMBAHASAN}

Penelitian yang dilakukan ini menggunakan desain penelitian jenis kuantitaf non eksperimental. Berdasarkan hasil dari uji normalitas dengan menggunakan alat bantu SPSS menunjukkan bahwa seluruh variabel dalam penelitian ini berdistribusi tidak normal. Sehingga analisis data yang digunakan yaitu statistik non-parametrik menggunakan aplikasi statistik Smart PLS dan SPSS untuk melihat korelasi antara keempat variabel penelitian.

Gambaran perilaku kerja kontraproduktif karyawan didapat dengan cara melakukan pengolahan data menggunakan analisis descriptive statistic. Nilai rata-rata perilaku kerja kontraproduktif organisasi karyawan cenderung rendah $(\mathrm{M}=0.33$ dan $\mathrm{SD}=0.49)$. Nilai rata-rata perilaku kerja kontraproduktif interpersonal karyawan juga cenderung rendah $(\mathrm{M}=0.33$ dan $\mathrm{SD}=0.48)$. Mengacu pada nilai maksimum yang diperoleh dari perilaku kerja kontraproduktif organisasi dan interpersonal, maka dapat dikatakan bahwa perilaku kerja kontraproduktif karyawan di perusahaan memang terjadi. Sementara itu, nilai rata-rata kontrak psikologis relasional karyawan tergolong tinggi $(\mathrm{M}=3.97$ dan $\mathrm{SD}=0.72)$. Nilai rata-rata kontrak psikologis transaksional karyawan tergolong sedang $(\mathrm{M}=3.0$ dan $\mathrm{SD}=0.61)$. Skala kontinum untuk kontrak psikologis relasional dan transaksional adalah 1 sampai dengan 5. Nilai Mean pada setiap variabel dapat dilihat pada tabel 1 di bawah ini.

Tabel 1. Gambaran Variabel Perilaku Kerja Kontraproduktif Karyawan PT.X

\begin{tabular}{ccccc}
\hline Dimensi & Min & Max & Mean & SD \\
\hline CWB & 0 & 2,46 & 0,33 & 0,47 \\
CWBI & 0 & 2,58 & 0,33 & 0,48 \\
CWBO & 0 & 2,70 & 0,33 & 0,49 \\
PC & 1 & 4,46 & 3,29 & 0,43 \\
PCR & 1 & 5,00 & 3,97 & 0,72 \\
PCT & 1 & 5,00 & 3,00 & 0,61 \\
\hline
\end{tabular}

${ }^{*} C W B=$ Perilaku Kerja Kontraproduktif, $C W B I=$ Perilaku Kerja Kontraproduktif Interpersonal, $C W B O=P e r i l a k u$ Kerja Kontraproduktif Organisasi, $P C=$ Kontrak Psikologis, $P C R=$ Kontrak Psikologis Relasional, $P C T=$ Kontrak Psikologis Transaksional.

\section{Uji Korelasi}

Peneliti menguji korelasi kontrak psikologis relasional antara partisipan laki-laki dan perempuan terhadap perilaku kerja kontraproduktif organisasi \& interpersonal. Variabel kontrak psikologis transaksional tidak masuk dalam uji korelasi seperti di atas, karena tidak ada perbedaan kontrak psikologis transaksional para partisipan laki-laki dan perempuan.

Melalui perhitungan korelasi di SPSS, didapatkan korelasi antara kontrak psikologis relasional dengan perilaku kerja kontraproduktif organisasi $(\mathrm{CWBO})(\mathrm{r}=-0.155, \mathrm{p}<0.01)$ dan perilaku kerja kontraproduktif interpersonal (CWBI) $(\mathrm{r}=-0.202, \mathrm{p}<0.01)$. Hasil perhitungan tersebut menandakan bahwa kontrak psikologis relasional pada partisipan laki-laki memiliki korelasi negatif yang signifikan terhadap perilaku kerja kontraproduktif organisasi sebesar $15,5 \%$ dan interpersonal sebesar 20,2\%. Selengkapnya dapat dilihat pada tabel 2 . 
Tabel 2. Uji Korelasi Kontrak Psikologis Relasional dan Transaksional terhadap Perilaku Kerja Kontraproduktif Organisasi dan Interpersonal pada Partisipan Laki-Laki

\begin{tabular}{ccccc}
\hline & CWBO & CWBI & PCR & PCT \\
\hline CWBO & 1 & & & \\
CWBI & $.760^{* *}$ & 1 & & \\
PCR & $-.155^{* *}$ & $-.202^{* *}$ & 1 & \\
PCT & .009 & .083 & $.164^{* *}$ & 1 \\
\hline
\end{tabular}

** correlation is significant at the 0.01 level (2 tailed)

* $C W B I=$ Perilaku Kerja Kontraproduktif Interpersonal, CWBO = Perilaku Kerja

Kontraproduktif Organisasi, $P C R=$ Kontrak Psikologis Relasional, $P C T=$ Kontrak

Psikologis Transaksional.

Melalui perhitungan korelasi di SPSS, didapatkan korelasi antara kontrak psikologis relasional dengan perilaku kerja kontraproduktif organisasi $(\mathrm{CWBO})(\mathrm{r}=-0.373, \mathrm{p}<0.01)$ dan perilaku kerja kontraproduktif interpersonal $(\mathrm{CWBI})(\mathrm{r}=-0,348, \mathrm{p}<0.01)$. Hasil perhitungan tersebut menandakan bahwa kontrak psikologis relasional pada partisipan perempuan memiliki korelasi negatif yang signifikan terhadap perilaku kerja kontraproduktif organisasi sebesar 37,3\% dan interpersonal sebesar 34,8\%. Selengkapnya dapat dilihat pada tabel 3.

Tabel 3. Uji Korelasi Kontrak Psikologis Relasional dan Transaksional terhadap Perilaku Kerja Kontraproduktif Organisasi dan Interpersonal pada Partisipan Perempuan

\begin{tabular}{ccccc}
\hline & CWBO & CWBI & PCR & PCT \\
\hline CWBO & 1 & & & \\
CWBI & $.851^{* *}$ & 1 & & \\
PCR & $-.373^{* *}$ & $-.348^{* *}$ & 1 & \\
PCT & .111 & .227 & -.068 & 1 \\
\hline
\end{tabular}

** correlation is significant at the 0.01 level (2 tailed)

* $C W B I=$ Perilaku Kerja Kontraproduktif Interpersonal, $C W B O=$ Perilaku Kerja

Kontraproduktif Organisasi, $P C R=$ Kontrak Psikologis Relasional, $P C T=$ Kontrak

Psikologis Transaksional.

\section{Uji Hipotesis}

Pengujian hipotesis dilakukan dengan melakukan tahap analisis SEM-PLS. Hipotesis 1a dan 1b penelitian ini adalah kontrak psikologis relasional berperan negatif sebagai prediktor perilaku kerja kontraproduktif terhadap organisasi $(\beta=-0.308, p<0.01)$ dan interpersonal $(\beta=-0.307$, $\mathrm{p}<0.01)$. Hasil pengujian hipotesis $1 \mathrm{a} \& 1 \mathrm{~b}$ dapat dilihat pada tabel 4.

Tabel 4. Uji Kontrak Psikologis Relasional sebagai Prediktor Perilaku Kerja Kontraproduktif Organisasi dan Interpersonal

\begin{tabular}{lccc}
\hline \multicolumn{1}{c}{ Variabel } & Nilai t & Nilai $\beta$ & Nilai $\mathrm{p}$ \\
\hline Outcomes: PCR & & & \\
Predictor: CWBO & 6.278 & -.308 & .000 \\
Predictor: CWBI & 6.064 & -.307 & .000 \\
\hline
\end{tabular}

$\mathrm{t}=$ Nilai uji signifikansi; $\beta=$ Koefisien regresi; $\mathrm{p}=$ Nilai uji signifikansi $\mathrm{p}$

$* C W B I=$ Perilaku Kerja Kontraproduktif Interpersonal, $C W B O=$ Perilaku Kerja Kontraproduktif Organisasi, PCR

$=$ Kontrak Psikologis Relasional.

Kontrak psikologis relasional diprediksi dapat berperan mengurangi perilaku kerja kontraproduktif organisasi sebesar $30,8 \%$ dan perilaku kerja kontraproduktif interpersonal sebesar 30,7\%. Sehingga, hipotesis 1a dan hipotesis $1 \mathrm{~b}$ didukung. 
Hipotesis $2 \mathrm{a}$ dan $2 \mathrm{~b}$ penelitian ini adalah kontrak psikologis transaksional berperan positif sebagai prediktor perilaku kerja kontraproduktif terhadap organisasi $(\beta=0.199, \mathrm{p}<0.01)$ dan interpersonal $(\beta=0.221, \mathrm{p}<0.01)$. Hasil pengujian hipotesis $2 \mathrm{a} \& 2 \mathrm{~b}$ dapat dilihat pada tabel 5 .

Tabel 5. Uji Kontrak Psikologis Transaksional sebagai Prediktor Perilaku Kerja Kontraproduktif Organisasi dan Interpersonal

\begin{tabular}{lccc}
\hline \multicolumn{1}{c}{ Variabel } & Nilai t & Nilai $\beta$ & Nilai $\mathrm{p}$ \\
\hline Outcomes: PCT & & & \\
Predictor: CWBO & 4.022 & .199 & .000 \\
Predictor: CWBI & 4.214 & .221 & .000 \\
\hline
\end{tabular}

$\mathrm{t}=$ Nilai uji signifikansi; $\beta=$ Koefisien regresi; $\mathrm{p}=$ Nilai uji signifikansi $\mathrm{p}$

* $C W B I=$ Perilaku Kerja Kontraproduktif Interpersonal, $C W B O=$ Perilaku Kerja Kontraproduktif Organisasi, PCT = Kontrak Psikologis Transaksional.

Maka kontrak psikologis transaksional diprediksi berperan mempengaruhi perilaku kerja kontraproduktif organisasi sebesar 19,9\% dan perilaku kerja kontraproduktif interpersonal sebesar $22,1 \%$. Sehingga, hipotesis $2 \mathrm{a}$ dan hipotesis $2 \mathrm{~b}$ didukung.

\section{KESIMPULAN DAN SARAN}

Berdasarkan hasil analisis data yang telah dipaparkan sebelumnya, beberapa simpulan yang dapat diambil dari penelitian ini sebagai berikut: (a) kontrak psikologis relasional berperan negatif dalam memprediksi terjadinya perilaku kerja kontraproduktif organisasi, (b) kontrak psikologis relasional berperan negatif dalam memprediksi terjadinya perilaku kerja kontraproduktif interpersonal, (c) kontrak psikologis transaksional berperan positif dalam memprediksi terjadinya perilaku kerja kontraproduktif organisasi, (d) kontrak psikologis transaksional berperan positif dalam memprediksi terjadinya perilaku kerja kontraproduktif interpersonal.

Hasil penelitian ini telah menunjukkan bahwa kontrak psikologis relasional berperan negatif dalam memprediksi perilaku kerja kontraproduktif organisasi dan interpersonal. Serta kontrak psikologis transaksional berperan positif dalam memprediksi perilaku kerja kontraproduktif organisasi dan interpersonal. Hal ini dapat diartikan bahwa semakin tinggi karyawan yang merasa memiliki kontrak psikologis yang bersifat relasional, maka akan semakin rendah menunjukkan perilaku kerja kontraproduktif baik organisasi maupun interpersonal. Begitu juga sebaliknya, semakin tinggi karyawan yang merasa memiliki kontrak psikologis yang bersifat transaksional, maka akan semakin tinggi menunjukkan perilaku kerja kontraproduktif baik organisasi maupun interpersonal.

Walaupun hasil penelitian sebelumnya belum menjelaskan lebih detail hubungan antara dimensi dari kedua variabel tersebut, namun hasil ini sejalan dengan beberapa penelitian sebelumnya yang menunjukkan adanya hubungan negatif antara kontrak psikologis karyawan relasional terhadap perilaku kerja kontraproduktif (Mai et al., 2016; Ali-Shah \& Ali-Shah, 2016; Griep et al., 2018). Sehingga, penelitian ini juga dapat mendukung hasil penelitian sebelumnya yang telah dilakukan oleh Mai et al., (2016); Ali-Shah \& Ali-Shah, (2016); dan Griep et al., (2018) yang belum menjelaskan dengan lebih detail untuk melihat hubungan antara keempat dimensi tersebut.

Penelitian yang dilakukan oleh Scandura dan Lankau (1997) menunjukkan bahwa laki-laki dan perempuan memiliki kontrak psikologis yang berbeda. Hal ini diasumsikan bahwa partisipan perempuan dalam berelasi lebih mementingkan afeksi agar hubungan tetap terjaga dengan baik, sehingga kontrak psikologis relasional harus diutamakan dibandingkan dengan transaksional, terutama dalam budaya orang Indonesia. Sehingga, perusahaan perlu menjaga kontrak psikologis 
relasional karyawan perempuan agar perilaku kerja kontraproduktif organisasi dan interpersonal dapat berkurang cukup signifikan. Sebaliknya, apabila sedikit saja kontrak psikologis relasional karyawan perempuan dilanggar, maka mereka akan langsung melakukan perilaku kerja kontraproduktif organisasi \& interpersonal. Hal ini disebabkan perilaku kerja kontraproduktif organisasi maupun interpersonal partisipan perempuan lebih tinggi dibandingkan dengan partisipan laki-laki.

Saran kepada para peneliti yang ingin mengeksplorasi lebih dalam mengenai variabel ini, maka peneliti menyarankan untuk (a) memperluas jangkauan penelitian dengan melibatkan perusahaanperusahaan lain yang memiliki jenis bisnis yang berbeda dan mempertimbangkan budaya masyarakat Indonesia agar lebih menarik, (b) menguji variabel lainnya yang bisa menjadi prediktor lebih kuat terhadap perilaku kerja kontraproduktif seperti negative affect ataupun rasa marah atau frustasi terhadap pekerjaan. Bennet dan Robinson (1995) melalui hasil penelitiannya mengatakan bahwa perilaku kerja kontraproduktif dapat disebabkan oleh rasa marah, frustasi, dan kecemasan. (c) perusahaan memiliki sistem-sistem yang mengakomodir karyawan agar memiliki kontrak psikologis relasional dan mempertahankan sistem kerja yang bertujuan untuk mencegah terjadinya perilaku kerja kontraproduktif.

\section{Ucapan Terima Kasih}

Peneliti menyampaikan banyak ucapan terima kasih kepada semua pihak yang telah mendukung proses penelitian dan pengambilan data ini terlaksana, khususnya pihak universitas, perusahaan, serta partisipan yang telah bersedia untuk memberikan waktunya dalam mengisi kuisioner penelitian. Peneliti sangat berterimakasih atas keterlibatan dalam membantu menyelesaikan proses penelitian ini dengan baik.

\section{REFERENSI}

Ali-Shah, T. \& Ali-Shah, S.Z. (2016). Combined Effects of Psychological Capital and Psychological Contract on Employees' Job Level Outcomes. European Journal of Business and Management, 8(26), 5-19.

Aubé, C., Rousseau, V., \& Tremblay, S. (2011). Team size and quality of group experience: The more the merrier? Group Dynamics: Theory, Research, and Practice, 15(4), 357-375.

Bennet, R. J., \& Robinson, S. L. (1995). A Typology of deviance workplace behaviors a multidimensional scaling study. The Academy of Management Journal, 38, 2. doi: http://doi.org/10.2307/256693

Bennet, R. J., \& Robinson, S. L. (2000). Development of a measure of workplace deviance. Journal of Applied Psychology, 85(3), 349-360. doi: https://doi.org/10.1037/00219010.85.3.349

Bordia, P., Restubog, S. L. D., \& Tang, R. L. (2008). When employees strike back investigating mediating mechanisms between psychological contract breach and workplace deviance. Journal of Applied Psychology, 93, 1104-1117. http://doi.org/10.1037/00219010.93.5.1104

Erkutlu, H., \& Chafra, J. (2013). Effects of trust and psychological contract violation on authentic leadership and organizational deviance. Management Research Review, 36, 828-848. doi: http://doi.org/10.1108/MRR-06-2012-0136

Fox, S., Spector, P. E., \& Miles, D. (2001). Counterproductive work behavior (cwb) in response to job stressors and organizational justice: some mediator and moderator tests for autonomy and emotions. Journal of Vocational Behavior, 59, 291-309. doi: https://doi.org/10.1006/jvbe.2001.1803 
Griep, Y., Vantilborgh, T., \& Jones, S. K. (2018). The relationship between psychological contract breach and counterproductive work behavior in social enterprises do paid employees and volunteers differ. Economic and Industrial Democracy, 1-19. https://doi.org/10.1177/0143831X17744029

Mai, K. M., Christian, J. S., Ellis, A. P. J., \& Porter, O. L. H. (2016). Examining the effects of turnover intentions on organizational citizenship behaviors and deviance behaviors a psychological contract approach. Journal of Applied Psychology, 101. doi: http://doi.org/10.1037/ap10000115

Millward, 1. J., \& Hopkins, L. (1998). Psychological contracts, organizational and job commitment. Journal of Applied Social Psychology, 28, 1530-1556. doi: https://doi.org/10.1111/j.1559-1816.1998.tb01689.x

Organ, D. W. (1997). Organizational citizenships behavior: Its construct cleanup time. Human Performance, 10, 85-97. https://.doi.org/10.1207/s15327043hup1002_2

Robinson, S. L., \& Morrison, E. W. (1997). When employees feel betrayed: A model of how psychological contract violation develops. The Academy of Management Review, 22(1), 226. doi: https://.doi.org/10.2307/259230

Rousseau, D. M. (1995). Psychological contracts in organizations: Under-standing written and unwritten agreements. London, UK: Sage. http://dx.doi.org/10.4135/9781452231594

Scandura, T.A., \& Lankau, M.J. (1997). Relationships of gender, family responsibility and flexible workhours to organizational commitment and job satisfaction, Journal of Organizational Behavior, $\quad 18, \quad 377-391 . \quad$ doi: https://doi.org/10.1002/(SICI)10991379(199707)18:4<377::AID-JOB807>3.0.CO;2-1

Suyasa, P.T.Y.S. (2018). Convergent evidence: Construct validation of an Indonesian version of interpersonal and organisational deviance scales. London: Taylor \& Francis Group.

Penney, L. M., \& Spector, P. E. (2005). Job stress, incivility, and counterproductive work behavior (CWB): The moderating role of negative affectivity. Journal of Organizational Behavior, 26(7), 777-796. doi: https://doi.org/10.1002/job.336

Yang, L. Q., Johnson, R. E., Zhang, X., Spector, P. E., \& Xu, S. (2012). Relations of interpersonal unfairness with counterproductive work behavior the moderating role of employee selfidentity. Journal Business Psychology, 28, 189-202. doi: https://doi.org/10.1007/s10869012-9271-8 